\title{
NOTICES OF MNRMOIRS.
}

\section{I.-Reporr of the Commitefe for investigating the Lower Carboniferods Flora at Gultane.}

Consisting of Dr. R. Kidston (Chairman), Dr. W. T. Gordon (Secretary), Dr. J. S. Flett, Professor E. J. Garwood, Dr. J. Horne, and Dr. B. N. Peach.

A NEW discovery of petrified plant-remains was made, in 1914 , $A$ at a point below high-water mark near Gullane, Haddingtonshire. The place.could only be reached at certain states of the tide. In order to accelerate collecting, blasting operations were proposed, and a grant voted at last meeting of the Association to meet the expenses. The locality, however, lies within the area of the Forth Estuary, and, although the military and police authorities readily gave permission to blast on the foreshore, it was considered inadvisable to act on that permission meanwhile. No part of the grant was used therefore, but sufficient material has been collected to amplify considerably the data already obtained. Some 150 thin sections of the material have been prepared and examined.

The flora represented in these sections is as follows:-

Lepidodendron veltheimianum, Sternb.

Stigmaria ficoides, Sternb. Botryopteris (?) antiqua, Kidston.
Bensonites fusiformis, R. Scott.

Pitys primeeva, Witham.

Pitys dayii, sp. nov.

Pitys, sp. nov.

Chief importance is attached to the specimens of Pitys, as so many well-preserved specimens have never been obtained elsewhere. Many of these examples had the bark preserved, while one of them consisted of a branch tip still clothed with needle-like leaves. Much light has been thrown on the stem structure of the genus, while the details of the connexion of leaf and stem have also been determined.

As regards the other plant types represented, it is interesting to note the similarity between the whole assemblage and the flora of the Pettycur Limestone at Pettycur, Fife. Indeed, the form Bensonites fusiformis, R. Scott, has not, so far, been recorded except from Pettycur. Both Gullane and Pettycur lie on the Forth, and the geological horizon of the rocks at both localities is not very different, so that the similarity of the floras is not surprising.

The specimens from Gullane occur in a greyish-white clastic rock, which on examination proved to be a highly decomposed volcanic ash. It is suggested that the decomposition of the ash, by vapours emitted from the volcano during its activity, produced solutions of mineral matter which caused the petrifaction of plant fragments included in the ash. These plant fragments occur quite sporadically through the rock, and they have evidently not been drifted in water. The petrifying solutions have been both calcareous and siliceous, so that some specimens are preserved in carbonate of lime, others in silica, while a few are partly in the one and partly in the other.

The perfection of the preservation is very striking, and it is proposed to continue collecting specimens when possible.

1 Read before the British Association, Section C (Geology), Neweastle, 1916. 
II.-The Palacoliths of Farnham. ${ }^{1}$ By Henty Bury, F.G.S.

THE information contained in a previous paper on the same subject (Proc. Geol. Assoc., vol. xxiv, pp. 178-201) is here revised and enlarged. The implements of the Alice Holt Plateau (including Terrace $A$ ) are usually large ( 5 to 8 inches long), and very few are later than the Chellean period. On Terrace $B$, on the contrary, the majority of unabraded implements are small (3 to 4 inches long), and quite 40 per cent are Acheulean. There are also many flakes, used as scrapers, which may be Mousterian. Terrace C, beyond a few Le Moustier flakes, yields no clear evidence of its age; but it is not impossible that the valley may have been excavated to this depth in early Chellean times. On Terrace $D$ unabraded implements are extremely rare, but among them are a few which may be of Le Moustier age. Another terrace (E) about 20 feet above the river is corered with a thick layer of drift, but has so far only yielded one implement.

\section{FEVIFWS.}

\section{I.-A practocleidus teretepes: a New Oxfordian Plestosaur} in the Hunterian Moseum, Glasgow University. By W. R. Smeldie, M.A., B.Sc. 'Trans. Roy. Soc. Edin., vol. li, pt. iii, 1916.

T $N$ this paper the author gives a very detailed account of the 1 remains of a Plesiosaur collected by $\mathrm{Mr}$. A. N. Leeds in the Oxford Clay of Peterborough. The skull and caudal region are missing, but otherwise the skeletion is nearly complete. In many respects this form is intermediate between Cryptocleidus and Tricleidus. Thus, in the fore-paddle the humerus articulates distally with the radius, ulna, pisiform, and a small accessory ossicle, as is the case in Tricleidus. On the other hand, in the shoulder-girdle the interclavicle is rery small or absent, and the triangular clavicles meet extensively in the middle line as in Cryptocleidus. For these and other reasons the author has established a new genus for the reception of this form. Many of the characters, however, which are regarded as indicating the higher organization of this t5pe, are certainly merely the result of the great extension of the ossification of the bones consequent upon the advanced age of the individual. Such characters are the extension forward of the scapulæ in advance of the clavicles, and the elongation of the dorsal rami of the scapulæ and of the postero-lateral processes of the coracoids.

This interesting paper is illustrated by nine text-figures and one plate.

${ }^{1}$ Read before the Geologists' Association, December 3, 1916. 